Jean-André de Luc that geological history was a sequence of seven vast periods, each corresponding to a day of creation.

In his medical work, Parkinson continued to demonstrate a concern for social justice. His 1799 book Medical Admonitions was intended to help poor families to recognize disease and understand when to pay for medical advice. In the following years, cheaper, condensed versions found a ready market with an increasingly literate working class. Parkinson became involved with local issues of late-eighteenth-century medicine: child labour, asylums and vaccination. His investigation of the horrific conditions endured by destitute children working in factories brought about local improvements, 30 years before any national legislation.

He was also one of the first people in London to offer smallpox vaccinations (he gave a dissecting microscope to his friend Edward Jenner, who pioneered the procedure). Less successfully, he served as a medical attendant to a private asylum. At a trial in 1810, he was involved in a notorious false commitment of a sane woman, for which he was widely criticized. That experience prompted a book the following year - Mad-houses: Observations on the Act for Regulating Mad-houses. Many of its suggestions for the humane treatment and legal protection of the mentally ill were finally incorporated in the 1845 Lunacy Act.

Given Parkinson's broad interests, passions and activities, it is perhaps surprising that his name lives on because of one essay - politely received at the time but not widely known. His description of the signs and symptoms of the disorder are still exemplary, although he had little to suggest in the way of causation or therapy. More than 50 years later, the great French neurologist Jean-Martin Charcot coined the expression maladie de Parkinson, and the essay began to gain a wider audience. I hope Lewis's book will do a similar job for the man himself.

Tilli Tansey is professor of the history of modern medical sciences at Queen Mary, University of London.

e-mail:t.tansey@qmul.ac.uk

\title{
Muscle, steam and combustion
}

\author{
Roger Fouquet applauds Vaclav Smil's vast survey of \\ the technologies powering human progress.
}

$\mathrm{V}$ aclav Smil's Energy and Civilization is a monumental history of how humanity has harnessed muscle, steam and combustion to build palaces and skyscrapers, light the night and land on the Moon. Want to learn about the number of labourers needed to build Egypt's pyramids of Giza, or US inventor Thomas Edison's battles with Nikola Tesla and George Westinghouse to electrify homes and cities, or the upscaling of power stations and blast furnaces in the twentieth century? Look no further.

Admired by Microsoft founder and philanthropist Bill Gates, Smil is a prolific writer on energy and environmental issues, with a penchant for history. This is especially valuable today, when renewables such as wind and solar power are set to disrupt the fossil-fuel-based energy system. Our use of energy has been transformed since the late nineteenth century with the extraction of oil and natural gas, the diffusion of technologies driven by electricity and the expansion of powerdistribution networks. History offers guidance on paradigm shifts, and how we adapt.

The book is a significantly revised, updated and more detailed version of Smil's Energy in

World History (Westview, 1994). It takes us back to prehistory to quantify the energy expended by foragers, hunters and agrarian societies. Smil uses evidence from the !Kung people in Botswana, the Maasai in Kenya and Alaskan whalers, and discusses 500,000-yearold spear tips found in South Africa and the

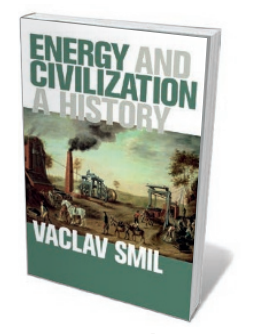

Energy and

Civilization: A

History

VACLAV SMIL

MIT Press: 2017. role of hunting in the extinction of the mammoths.

From the fifth millennium $\mathrm{BC}$ to the middle of the second millennium AD, civilizations such as those of ancient Egypt, Rome and China through to medieval and Renaissance Europe collectively invented technologies reliant on muscle power, wind and water, along with increasingly refined wheels and pulleys. Smil explains that the shift from human to animal power and the use of irrigation, fertilizer and crop rotation were key to increasing agricultural yields and ultimately population size. He reveals how settlements in warm climates, such as Mesoamerica or India, depended on an area of agricultural land 60 times greater than that of the average town at the time. It was 100 times greater in colder climates such as northern Europe, where forests providing fuel for heat were also needed. The ability to mine and use energy-dense fossil fuels altered the 'energy footprint' of towns and cities and allowed urban centres to become denser. Smil dwells on genius scientists and heroic engineers of the first and second industrial revolutions between 1760 and 1913, and the high-tech takeover

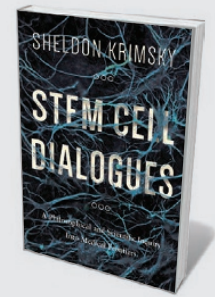

Stem Cell Dialogues

Sheldon Krimsky (Columbia Univ. Press, 2017)

Sociologist Sheldon Krimsky explores the history

of stem-cell research through an unusual lens:

Socratic dialogues. From the ethics of cloning to the politics of using embryonic stem cells, the scenarios examine the achievements and controversies of regenerative medicine.

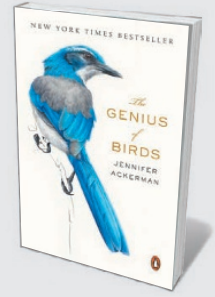

The Genius of Birds

Jennifer Ackerman (Penguin, 2017)

In a study scattered through with personal observations, science writer Jennifer Ackerman extols the startling intelligence of birds. New Caledonian crows can fashion tools, magpies recognize their own reflections and western scrub jays may hold "funerals". 


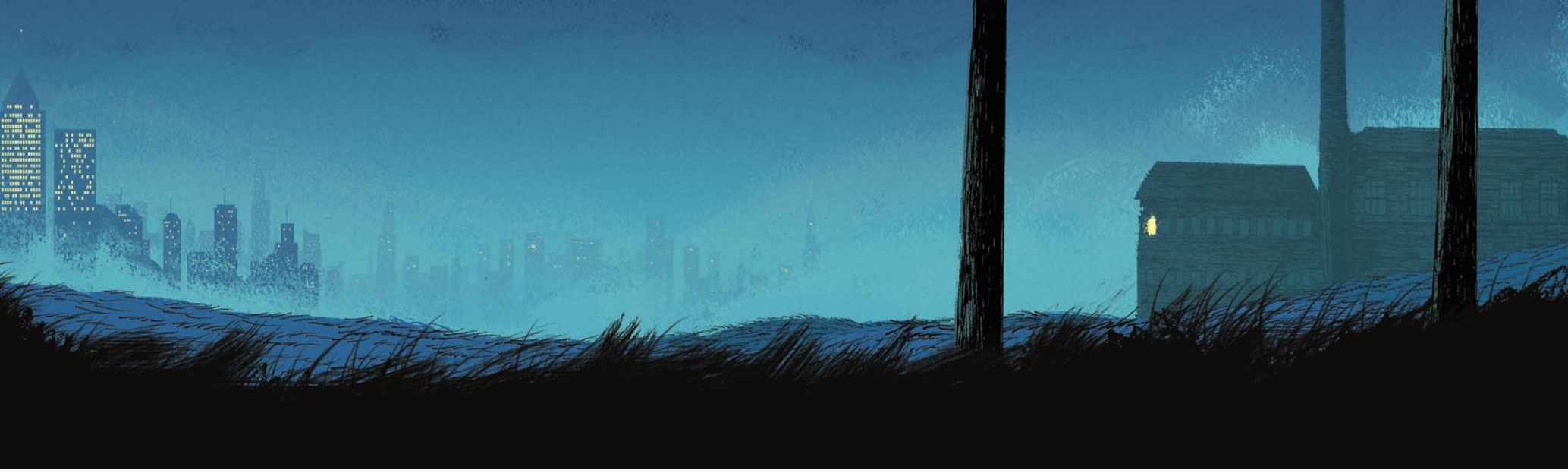

of the twentieth century.

He is not a historian. There is no strong narrative or testing of a central hypothesis. But he does provide economic and geopolitical context. For instance, he touches on the importance of the Organization of the Petroleum Exporting Countries and the oilprice shocks of the 1970s in ushering in a new energy era. Larger petroleum reserves, alternative energy sources and more efficient technologies were frantically sought to minimize the economic damage from the oil-price hike.

Smil concludes with some broader points. He notes that advances in the capacity to harness energy have led to huge improvements in human well-being, including greater mobility and illumination. However, he stresses that many political leaders in the twentieth century, from Vladimir Lenin to Franklin Delano Roosevelt, have been let down by the promise of economic growth boosted by huge energy investments, such as hydroelectric dams and nuclear power stations. These are not panaceas, because abundant energy is a necessary but not sufficient condition for development.

Similarly, energy subsidies - mostly for fossil-fuel production and consumption - may do more harm than good. Running at around $6.5 \%$ of global gross domestic product, they lock economies into energy-intensive and polluting consumption patterns, making them more vulnerable to price shocks, trade-balance deficits, political pressures from energy companies and pollution. Furthermore, Smil warns, humanity's ability to harness greater power could lead it down several very different pathways, including melting the entire Antarctic ice sheet and raising sea levels by 58 metres. Ultimately, he warns that the long-term survival of our high-energy civilization remains uncertain.

Smil's detailed review of military applications of energy is fascinating, and unusual. He notes, for instance, that the atomic bomb dropped on Hiroshima by US forces on 6 August 1945 produced 63,000 gigajoules of energy. On other negative aspects of energy production and consumption, the book is weaker. Coal mining and nuclear accidents such as the disasters in Chernobyl, Ukraine, and Fukushima, Japan, in 1986 and 2011, respectively - have scarred communities. Yet the most lethal side-effects of energy use have been car accidents and air pollution, each only briefly mentioned. Traffic accidents cause almost 1.3 million deaths per year. Harder to quantify, air pollution has also led to millions of lost lives in the past 200 years.

Although these risks have been tolerated, Smil reminds us that concerns about air pollution have encouraged transitions away from coal in Europe and China. Chinese investment in wind turbines and solar panels has driven down the price of renewable power so that in many locations it is the cheapest source of electricity. Although it is too early to say, we could be witnessing a dramatic new chapter in energy history. But a lesson from history is that solving one environmental problem often leads to another: increased energy consumption.

Because of the vast literature on energy written since Smil's 1994 history, this radically revised version is $60 \%$ longer. Structurally and in terms of message, the books are similar, however, probably because the new literature has not fundamentally changed our interpretation of the energy landscape. It is also a credit to Smil's original and enlightening way of seeing energy in world history. Read it and be dazzled by the panoply of ways in which humanity has powered progress, with forces, materials and sheer blazing ingenuity.

Roger Fouquet is an associate professorial research fellow at the Grantham Research Institute on Climate Change and the Environment at the London School of Economics and Political Science. e-mail:r.fouquet@lse.ac.uk

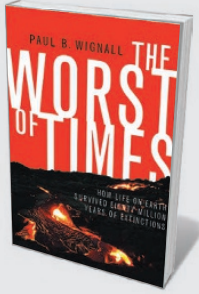

The Worst of Times

Paul B. Wignall (Princeton Univ. Press, 2017) Palaeontologist Paul Wignall journeys through the tumultuous end of the Permian period, some 260 million years ago, on supercontinent Pangaea. The era's catastrophic extinctions, he suggests, could be linked to its unprecedented levels of volcanism.

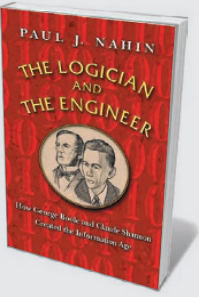

The Logician and the Engineer

Paul J. Nahin (Princeton Univ. Press, 2017)

Proving that two heads are better than one in innovation, Paul Nahin examines how engineer Claude Shannon used mathematics devised by George Boole 90 years before to develop electrical circuits - and traces the advancement of high technology such as the abstract 'Turing machine'. 